\title{
Concentration-Dependent Requirement for Local Protein Synthesis in Motor Neuron Subtype-Specific Response to Axon Guidance Cues
}

\author{
Stéphane Nédelec, ${ }^{1}$ Mirza Peljto, ${ }^{1}$ Peng Shi ${ }^{4}$ Mackenzie W. Amoroso, ${ }^{5}$ Lance C. Kam, ${ }^{4}$ and Hynek Wichterle ${ }^{1,2,3}$ \\ Departments of ${ }^{1}$ Pathology and Cell Biology and ${ }^{2}$ Neuroscience, ${ }^{3}$ Center for Motor Neuron Biology and Disease, College of Physicians and Surgeons, PS \\ 14-434, Columbia University, New York, New York 10032, ${ }^{4}$ Department of Biomedical Engineering, Columbia University, New York, New York 10027, and \\ ${ }^{5}$ Project A.L.S./Jenifer Estess Laboratory for Stem Cell Research, Columbia University, New York, New York 10032
}

Formation of functional motor circuits relies on the ability of distinct spinal motor neuron subtypes to project their axons with high precision to appropriate muscle targets. While guidance cues contributing to motor axon pathfinding have been identified, the intracellular pathways underlying subtype-specific responses to these cues remain poorly understood. In particular, it remains controversial whether responses to axon guidance cues depend on axonal protein synthesis. Using a growth cone collapse assay, we demonstrate that mouse embryonic stem cell-derived spinal motor neurons (ES-MNs) respond to ephrin-A5, Sema3f, and Sema3a in a concentrationdependent manner. At low doses, ES-MNs exhibit segmental or subtype-specific responses, while this selectivity is lost at higher concentrations. Response to high doses of semaphorins and to all doses of ephrin-A5 is protein synthesis independent. In contrast, using microfluidic devices and stripe assays, we show that growth cone collapse and guidance at low concentrations of semaphorins rely on local protein synthesis in the axonal compartment. Similar bimodal response to low and high concentrations of guidance cues is observed in human ES-MNs, pointing to a general mechanism by which neurons increase their repertoire of responses to the limited set of guidance cues involved in neural circuit formation.

\section{Introduction}

Function of the nervous system depends on the formation of precise neural circuits. Specificity of neuronal connections is well illustrated in the motor system, where individual axons emanating from hundreds of spinal motor neuron subtypes follow prescribed trajectories to innervate defined muscle groups (Dasen and Jessell, 2009). In vivo and in vitro studies established that two families of repulsive guidance cues-secreted semaphorins and ephrins_-play a crucial role in motor axon navigation (see Fig.

Received Aug. 10, 2011; revised Nov. 11, 2011; accepted Dec. 8, 2011.

Author contributions: S.N. and H.W. designed research; S.N., M.P., and M.W.A. performed research; P.S. and L.C.K. contributed unpublished reagents/analytic tools; S.N. and H.W. analyzed data; S.N. and H.W. wrote the paper.

This project was supported by grants from the Research Initiatives in Science and Engineering, the Gatsby Foundation, and the Center for Motor Neuron Biology and Disease, and by NIH Grants NS058502 and NS055923. S.N. was in part supported by a fellowship from the Families of SMA. M.P. was supported by Department of Defense Grant 522050 and NIH Training Grant HD055165. M.W.A. was supported by the Project A.L.S. Foundation. We are grateful to R. P. C. Manns, G. M. W. Cook, C. E. Holt, and R. J. Keynes for sharing unpublished data on concentrationdependent growth cone collapse of DRG neurons. We thank Artur Kania, Esteban Mazzoni, and members of the Wichterle laboratory for helpful discussion and critical review of the manuscript; Susan Brenner-Morton and Thomas Jessell for the RALDH2 antibody; and Morris Reichlin for the anti-P protein serum.

The authors declare no financial conflicts of interest.

Correspondence should be addressed to Hynek Wichterle, Center for Motor Neuron Biology and Disease, College of Physicians and Surgeons, PS 14-434, Columbia University, 630 W. 168th Street, New York, NY 10032. E-mail: hw350@columbia.edu.

M. Peljto's present address: University of Colorado, Department of Chemical and Biological Engineering, Boulder, C0 80309.

P. Shi's present address: Department of Mechanical and Biomedical Engineering, City University of Hong Kong, 83 Tat Chee Avenue, Kowloon, Hong Kong, China.

DOI:10.1523/JNEUROSCI.4176-11.2012

Copyright $\odot 2012$ the authors $\quad 0270-6474 / 12 / 321496-11 \$ 15.00 / 0$
$1 A, B$ ) (Bonanomi and Pfaff, 2010). However, limited access to primary motor neurons prevented detailed molecular analysis of intracellular pathways underlying subtype-specific responses of motor axons to guidance cues.

In the past few years, pharmacological studies established that axonal protein translation is a key component of axon guidance, necessary for the attraction and repulsion of growth cones by multiple guidance molecules (Jung and Holt, 2011). However, these studies were recently challenged by a report concluding that responses to guidance cues do not require local protein synthesis (Roche et al., 2009). Several parameters might contribute to the reported discrepancy. First, dissection of primary neurons from embryos often leads to axon injury and to subsequent changes in axonal mRNA transport and translation (Gumy et al., 2010). Therefore, differential handling of tissue after dissection might influence whether local protein synthesis is involved during axon guidance. Second, different concentrations of guidance cues might elicit qualitatively different growth cone collapse programs, only some of which might be dependent on local protein synthesis (Li et al., 2004; Brown et al., 2009; Jaffrey, 2009).

Here we used an embryonic stem cell (ESC)-based system that provides a virtually unlimited source of ESC-spinal motor neurons (ES-MNs) (Wichterle et al., 2002; Peljto et al., 2010) to examine motor neuron subtype specificity of axon guidance responses and its dependence on protein synthesis. Unlike primary motor neurons, whose axons are often injured during dissection, ES-MNs plated as embryoid bodies never undergo axotomy. Furthermore, ESCs can be differentiated into distinct motor neuron 
A

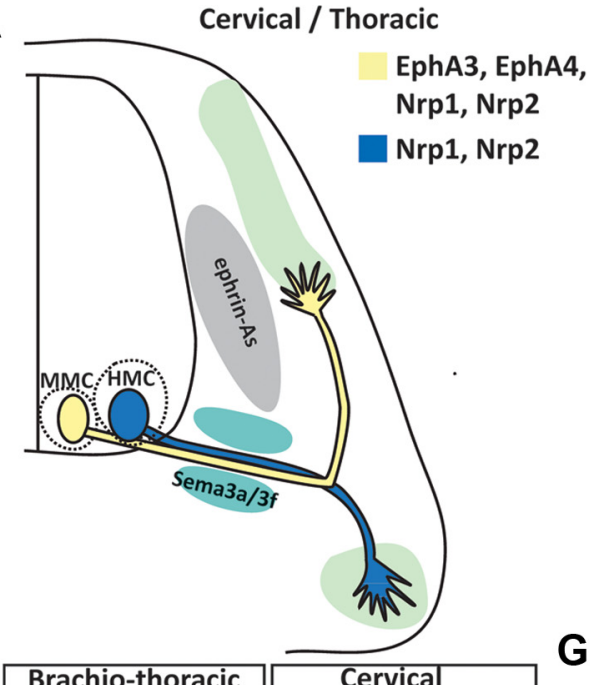

B

Brachial
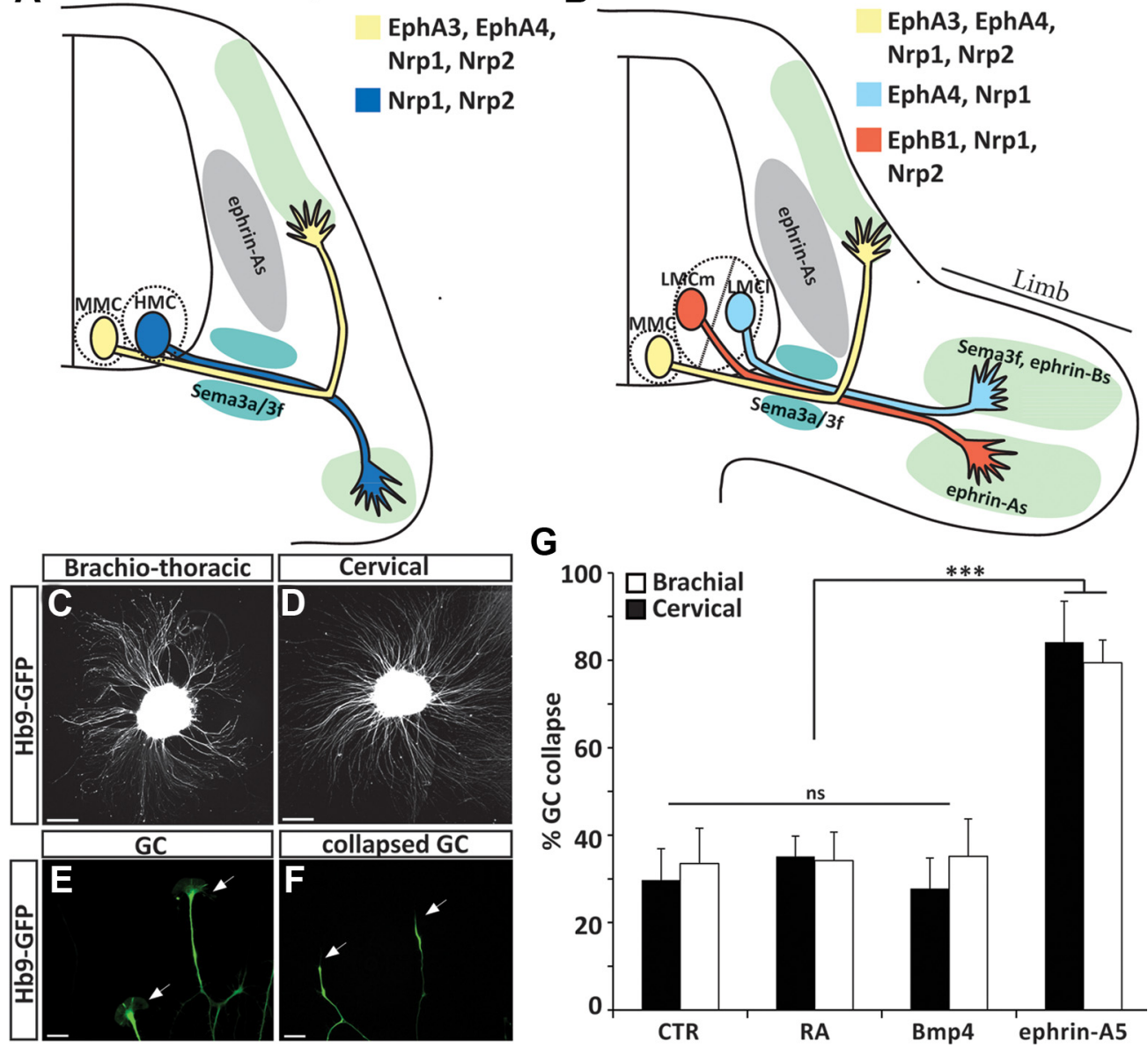

Figure 1. Growth cone collapse assay as a tool to study the response of ES-MN axons to repulsive guidance cues. $A, B$, Schematic representation of spinal motor neuron projections at brachial and cervical/thoracic level of the spinal cord. LMCl, lateral subdivision of the LMC. Guidance cues and receptors previously implicated in motor neuron subtype-specific axon guidance are indicated. $C, \boldsymbol{D}$, Brachiothoracic ( $($ ) and cervical (D) ES-MNs show profuse axon outgrowth on laminin substrate. Scale bar, $80 \mu \mathrm{m}$. $\boldsymbol{E}$, Typical growth cones (arrowheads) observed at the tip of ES-MN axons (cervical). Scale bar, $15 \mu \mathrm{m}$. F, Following exposure to ephrin-A5, growth cone collapse leading to the disappearance of filopodia and lamellipodia and the formation of a retraction bulb. Scale bar, $15 \mu \mathrm{m}$. $\boldsymbol{G}$, Growth cones of brachiothoracic and cervical motor axons collapse efficiently when exposed to ephrin-A5 $(n=5)$. Two-way ANOVA with post hoc analysis, ${ }^{* * *} p<0.001$. n.s., No significance; GC, growth cone. Error bar indicates SD.

subtypes, which, upon implantation in the developing chick neural tube, exhibit subtype-specific axon pathfinding comparable to in vivo motor neurons (Peljto et al., 2010). In vitro generated ES-MNs might thus represent a valuable and powerful tool for systematic pharmacological and biochemical study of axon guidance (Soundararajan et al., 2010). Here we demonstrate that in vitro cultured ES-MNs, which were never exposed to the embryonic environment, acquire expected subtype-specific responsiveness to guidance cues. We show that these responses are concentration dependent and that only the response to low concentrations of semaphorins is dependent on axonal protein synthesis. Therefore, ES-MNs can serve as a pharmacologically and biochemically accessible system to define motor neuron subtypespecific signal transduction pathways activated in response to varying concentrations of guidance cues.

\section{Materials and Methods}

Embryonic stem cell culture and differentiation. To generate cervical motor neurons, differentiation of ESCs (HBG3 male ESC line) under retinoic acid (RA) and Hedgehog agonist (Hh) conditions was performed as previously described (Wichterle et al., 2002). Brachiothoracic motor neurons were obtained by differentiation of ESC under conditions relying on endogenous sources of caudalizing and ventralizing (CV) signals (CV differentiation) as described by Peljto et al. (2010). ESC-derived human motor neurons were differentiated from the HuES-3-Hb9:GFP ESC line (male ESC line) as described by Boulting et al. (2011).

Collapse assays. Six to seven embryoid bodies at day 6 of differentiation were plated on polyornithine-coated $\left(20 \mu \mathrm{g} / \mathrm{ml}\right.$, overnight at $\left.37^{\circ} \mathrm{C}\right)$, laminin-coated $\left(5 \mu \mathrm{g} / \mathrm{ml}, 2 \mathrm{~h}\right.$ at $\left.37^{\circ} \mathrm{C}\right)$ coverslips in 50\% ADMEM/F12, 50\% Neurobasal medium, supplemented with N2 (Invitrogen). After $16 \mathrm{~h}$, Sema3a-Fc, Sema3f-Fc, ephrin-A5-Fc, Bmp4 (R\&D Systems), or RA (Sigma) was applied in the culture medium. To block protein synthesis, cycloheximide $(10 \mu \mathrm{M})$ was added $5 \mathrm{~min}$ prior to addition of the cues. To block the interaction between Neuropilin-1 (Nrp1) and Sema3a, an antiNrp1 antibody (AF 566, R\&D Systems) was added 30 min prior to Sema3a addition. Cells were fixed with a prewarmed $\left(37^{\circ} \mathrm{C}\right)$ solution of $4 \%$ paraformaldehyde containing 10\% sucrose. Coverslips were mounted, and the collapse rate of GFP-positive axons was assessed using a $40 \times$ objective. Ninety to 300 growth cones were counted per condition. To assess the specific collapse rate of lateral motor column (LMC) axons, fixed embryoid bodies were stained with rabbit anti-RALDH2 antibody (Sockanathan and Jessell, 1998) and a donkey anti-rabbit Cy3 (1/1500) secondary antibody (Jackson Immunoresearch). Human motor neurons were stained for GFP (rabbit anti-GFP, Invitrogen) and F-actin (Phalloidin Alexa-594, Invitrogen). Collapse rate was then assessed as mentioned above. A minimum of three independent experiments were performed per condition. Percentages are means between experiments. Error bars represent the SDs between replicates. Statistical analysis were performed using one-way or two-way ANOVA followed by post hoc analysis (SigmaPlot software). 
Collapse assays in microfluidic chambers. Microfluidic chambers (Shi et al., 2010) were assembled on glass coverslips. Glass was coated sequentially with polyornithine $(20 \mu \mathrm{g} / \mathrm{ml}, 1 \mathrm{~h}$ at $\left.37^{\circ} \mathrm{C}\right)$ and laminin $\left(7 \mu \mathrm{g} / \mathrm{ml}, 2 \mathrm{~h}\right.$ at $\left.37^{\circ} \mathrm{C}\right)$. Embryoid bodies differentiated into motor neurons were placed in the cell body compartment of the chamber and cultured for $24 \mathrm{~h}$ in 50\% ADMEM/ F12, 50\% Neurobasal, supplemented with B27 (Invitrogen). To provide optimal trophic support for motor neurons without interfering with the response to guidance cues, the medium on the cell body side of the chamber is supplemented with growth factors (final concentration: GDNF $5 \mathrm{ng} / \mathrm{ml}$, BDNF $5 \mathrm{ng} / \mathrm{ml}$, hepatocyte growth factor (HGF) $5 \mathrm{ng} / \mathrm{ml}$, CNTF $5 \mathrm{ng} / \mathrm{ml}$; R\&D Systems). Twenty minutes before the addition of Sema3a or Sema3f, $10 \mu \mathrm{M}$ cycloheximide or DMSO is added on the axon side of the chamber.

Microfluidic chambers and micropatterning. Stripe assays in microfluidic chambers were performed as described by Shi et al. (2010). Briefly, Protein A stripes are patterned on glass coverslips using a stamping method. Microfluidic chambers were applied on the coverslip, aligned with the stripes. A $3 \%$ fetal bovine se$\mathrm{rum} / 3 \%$ BSA solution containing $10 \mu \mathrm{g} / \mathrm{ml}$ Sema3f-Fc in PBS was applied to the Protein-A stripes for $30 \mathrm{~min}$ then washed thoroughly with PBS. Coverslips were then coated with polyornithine and laminin as described above. Cultures of ES-MNs are performed as described above. Sixteen hours after plating of the cells, $10 \mu \mathrm{M}$ cycloheximide (Wichterle et al., 2002; Peljto et al., 2010) or DMSO is added in the axon compartment, and neurons are cultured for additional $8 \mathrm{~h}$ before being fixed and processed for imaging.

Quantification of stripe assays. GFP intensity was measured in abutting windows of equivalent size, one covering the Sema3f stripe and another one in the adjacent laminin stripe. The ratio of the two signals determines the "guidance" index. For each condition, 8 stripes in two independent chambers have been analyzed (16 stripes per conditions). Statistical analyses were performed using the $t$ test.

Fluorescent in situ hybridization and immunohistochemistry on dissociated ES-MNs. Dissociated ES-MNs were plated on glass coverslips (5000 cells $/ \mathrm{cm}^{2}$ ) and cultured overnight. Cells were fixed with $4 \%$ paraformaldehyde for $15 \mathrm{~min}$ at room temperature, washed three times with PBS, and processed for immunostaining or in situ hybridization (ISH). ISH was performed as described by Batish et al. (2011). Briefly, 48 individual TAMRA single-labeled 20 mer oligonucleotides complementary to mouse Slit 2 and the $\beta$-actin mRNA sequence were designed as described by Raj et al. (2008) and were obtained from Biosearch Technologies. Cells were then processed for ISH.

For the detection of $\mathrm{P}$ ribosomal proteins and eIF4E, fixed cells were incubated with a human autoantibody against P0, P1, and P3 ribosomal proteins (generous gift of Dr. Morris Reichlin, University of Oklahoma, Oklahoma City, OK), a rabbit anti-eIF4E antibody (Ab 9742, Cell Signaling Technology) at $4^{\circ} \mathrm{C}$ overnight. Cy3 goat anti-human IgG or anti-rabbit secondary antibodies (Jackson Immunoresearch) were used to visualize the immunostaining.

Quantification of phospho-4EBP1 following exposure to guidance cues. Three to four minutes after addition of the guidance cues in the culture medium, the cells were fixed and processed for immunostaining as described above with a rabbit anti-P-4EBP1 (Ab 2855, Cell Signaling Technology). The intensity of the P-4EBP1 signal was measured in 20 growth cones (10 growth cones per experiment in two independent experiments) and normalized to the GFP signal. Statistical analyses were performed using one-way ANOVA on ranks.

\section{Results}

ES-MN axons respond to biologically relevant guidance cues The formation of precise neuronal connections relies on the differential interpretation of guidance cues by related groups of neurons innervating distinct targets. ESCs can be differentiated into subtypes of motor neurons appropriately innervating their expected targets in vivo (Yohn et al., 2008; Peljto et al., 2010). $\mathrm{RA} / \mathrm{Hh}$ treatment generates primarily cervical motor neurons of median motor column (MMC) and hypaxial motor column (HMC) identities (Fig. 1A,B) (Wichterle et al., 2002). Differentiation under $\mathrm{CV}$ condition generates more posterior brachiothoracic motor neurons, including limb-innervating LMC ES-MNs (Fig. 1 A,B) (Peljto et al., 2010).

We took advantage of ES-MN subtype diversity to determine whether in vitro generated neurons acquire the ability to respond to guidance cues independent of transplantation into the embryonic spinal cord. Growth cone collapse assay is a simple and quantitative method to assess cervical and brachiothoracic ES-MN responses to guidance molecules. On day 5-6 of differentiation (equivalent of mouse E9.5-E10.5), ES-MNs undergo a period of active axon outgrowth when plated on permissive substrate (Fig. $1 C, D$ ). Motor axons exhibit well elaborated growth cones (Fig. $1 E$ ) that can be specifically identified by the expression of GFP under the control of the motor neuron-specific $\mathrm{Hb} 9$ promoter (Wichterle et al., 2002). First, we determined by timelapse microscopy the kinetics of the ES-MN response to ephrinA5, a chemorepulsive cue previously implicated in the guidance 

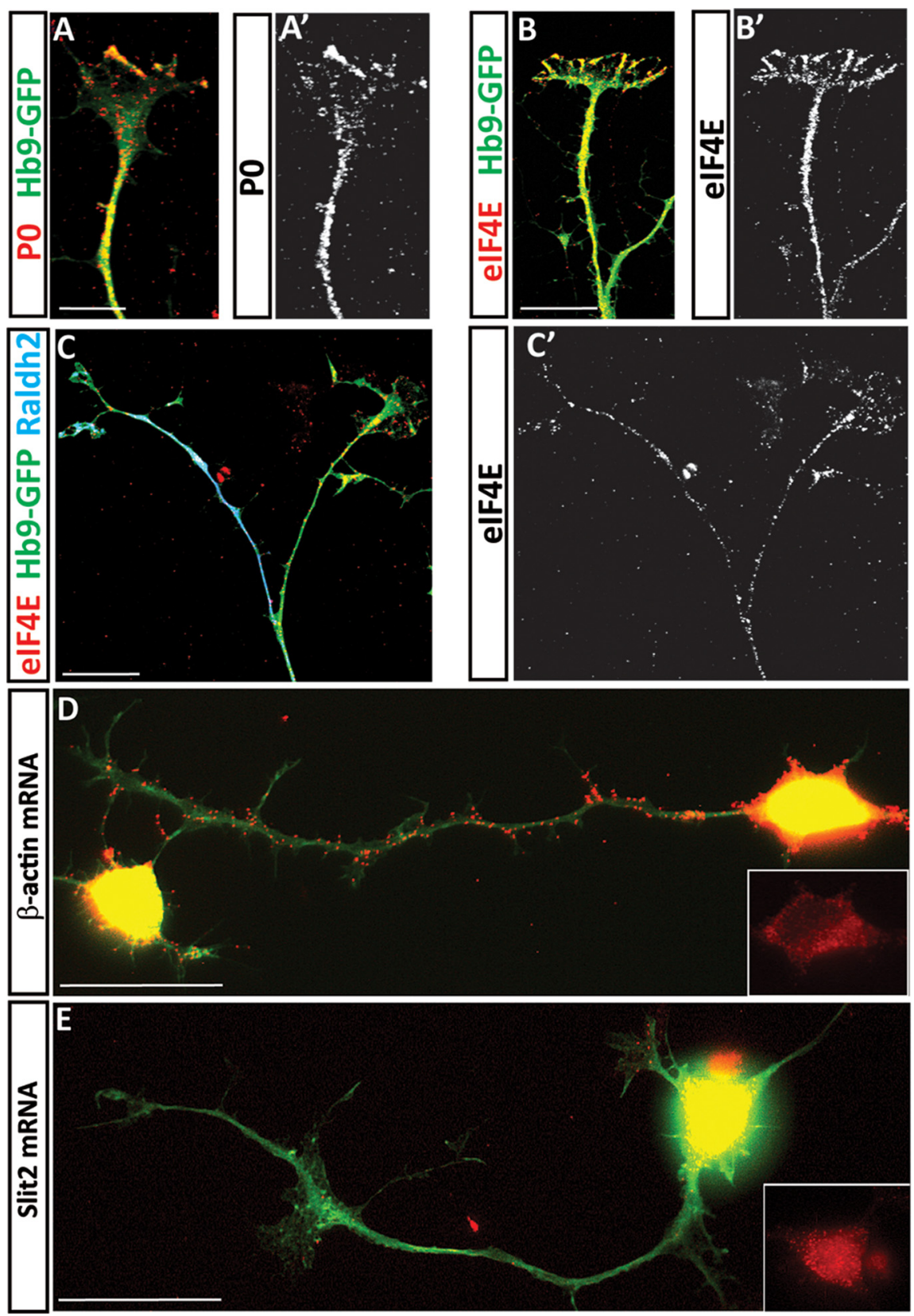

Figure 3. Axons of ES-MNs contain components of the translation machinery and $\beta$-actin mRNA. Immunocytochemistry revealed the presence of ribosomal $P$ proteins and the translation initiation factor elF4E in ESC-derived motor neuron axons $\left(\boldsymbol{A}, \boldsymbol{A}^{\prime}\right.$, $\boldsymbol{B}, \boldsymbol{B}^{\prime}$, cervical ES-MNs; $\boldsymbol{C}$, brachiothoracic ES-MNs). Many motor axons also contain $\beta$-actin mRNA, as revealed by in situ hybridization with a mixture of TAMRA-labeled oligo-probes, while Slit2 mRNA is observed in cell bodies but not in axons $(\boldsymbol{D}, \boldsymbol{E}$, cervical ES-MNs). Scale bars, $20 \mu \mathrm{m}$.

of motor axons in vivo and shown to induce motor neuron growth cone collapse in vitro (Ohta et al., 1997; Eberhart et al., 2000; Helmbacher et al., 2000; Kania et al., 2000; Marquardt et al., 2005; Gallarda et al., 2008; Kao and Kania, 2011). At 300 ng/ml ephrin-A5, a concentration of ephrin-A used in previous studies (Marquardt et al., 2005; Gallarda et al., 2008), we observed that nearly all ES-MN growth cones collapsed and axon shafts retracted in 15-20 min (data not shown) (Fig. 1F). Ephrin-A5 (300 $\mathrm{ng} / \mathrm{ml}$ ) induces a strong collapse response of both cervical and brachiothoracic ES-MN growth cones $(84.1 \%$ and $79.4 \%$, respectively; $p<0.001$ ) (Fig. $1 G$ ). Based on these observations, we concluded that a 20 min growth cone collapse assay can be used to assess the responsiveness of cervical or brachiothoracic ES-MNs to relevant guidance cues.

\section{Subtype-specific response of ES-MNs to ephrin-A5}

Are ES-MNs correctly programmed and able to respond to guidance cues according to their subtype identity? Close to $40 \%$ of brachiothoracic ES-MNs are limbinnervating LMC motor neurons. The vast majority of these acquire the molecular identity of medial LMC (LMCm) motor neurons, predicted to project their axons to the ephrin-As-rich ventral limb (Fig. $1 B$ ) (Eberhart et al., 2000; Kania and Jessell, 2003; Peljto et al., 2010). LMCm ES-MNs should be largely resistant to ephrin-A5induced collapse, while non-LMC neurons should be responsive (Kania et al., 2000; Marquardt et al., 2005; Gallarda et al., 2008; Kao and Kania, 2011).

To examine subtype-specific guidance, we first developed methods to distinguish LMC and non-LMC motor axons. We observed that while LMC marker Foxp1 marks only nuclei of neurons (Fig. 2A), RALDH2 is coexpressed with Foxp 1 in LMC ES-MNs and can be traced to distal axons in vivo (Fig. $2 B$ ) (Sockanathan and Jessell, 1998) and in vitro (Fig. 2C). Therefore, RALDH 2 staining provides a reliable way to distinguish between LMC and non-LMC growth cones.

At the ephrin-A5 concentration previously used to induce growth cone collapse $(300 \mathrm{ng} / \mathrm{ml})$, we did not detect a differential response between LMC and non-LMC axons (Fig. 2D). We reasoned that a subtype-specific response might be revealed only at lower concentrations of guidance cues as demonstrated for retinal ganglion cells (RGCs) (Petros et al., 2010). We thus exposed brachiothoracic neurons to different concentrations of ephrin-As and determined their dose-response curve (Fig. 2D,E). At a submaximal dose of ephrin-A5 $(50 \mathrm{ng} / \mathrm{ml})$, we observed preferential collapse of nonLMC axons $(73.4 \%$ of non-RADLH2 axons; $p<0.001)$, while LMC axons collapsed at a significantly lower rate $\left(52.8 \%\right.$ of RADLH2 ${ }^{+}$ax- $^{-}$ ons; $p<0.05$ ) (Fig. 2D).

These observations demonstrate that Ephrin-A5 induces a subtype-specific collapse response of ES-MN axons, but that this specificity is eroded at high concentrations of the guidance cue.

\section{Ephrin-A5-dependent collapse is protein synthesis} independent

Provided that ES-MNs can be used to study specific responses to guidance molecules, we decided to interrogate intracellular path- 



Figure 4. Concentration-dependent and subtype-specific requirement for local protein synthesis during growth cone collapse in response to semaphorins. $\boldsymbol{A}$, A Sema3a concentration of 300 $\mathrm{ng} / \mathrm{ml}$ induces a strong collapse of brachiothoracic ES-MN growth cones, while cervical ES-MN growth cones remain largely insensitive ( $n=4)$. At a Sema3a concentration of $900 \mathrm{ng} / \mathrm{ml}$, both populations respond equally well ( $n=4$; two-way ANOVA with post hoc analysis). Error bar indicates SD. $\boldsymbol{B}$, Translation inhibitor cycloheximide significantly decreases the collapse response of brachiothoracic motor axons at 100 and $300 \mathrm{ng} / \mathrm{ml} \mathrm{Sema3a}(n=4)$ but not at $900 \mathrm{ng} / \mathrm{ml}(n=4$; two-way ANOVA with post hoc analysis). Error bar indicates SD. C, ES-MN growth cones can adapt to a high concentration of Sema3a. At $900 \mathrm{ng} / \mathrm{ml} \mathrm{Sema3a,} \mathrm{the} \mathrm{rate} \mathrm{of} \mathrm{collapsed} \mathrm{growth} \mathrm{cone} \mathrm{is} \mathrm{back} \mathrm{to} \mathrm{control} \mathrm{(CTR)} \mathrm{level} \mathrm{after} 3 \mathrm{~h}$ ( $t$ test vs CTR). D-G', 4EBP-1 staining in brachiothoracic (Brach.) and cervical (Cerv.) ES-MN growth cones upon addition of Sema3a at low ( $300 \mathrm{ng} / \mathrm{ml}$ ) or high concentration ( $900 \mathrm{ng} / \mathrm{ml})$. Scale bar, $10 \mu \mathrm{m}$. $\boldsymbol{H}$, Relative fluorescence of 4 EBP-1 (normalized to GFP) in cervical or brachial ES-MN growth cones upon Sema3a or Sema3f at low ( $300 \mathrm{ng} / \mathrm{ml})$ or high concentration ( $900 \mathrm{ng} / \mathrm{ml})$ (one-way ANOVA on ranks). Error bar indicates SEM. I, Cycloheximide does not affect the collapse response of cervical motor axons at $900 \mathrm{ng} / \mathrm{ml} \mathrm{Sema3a}(n=4)$. J, Cycloheximide significantly decreases the collapse response of cervical motor axons at $100 \mathrm{and} 300 \mathrm{ng} / \mathrm{ml}$ Sema3f but not at $900 \mathrm{ng} / \mathrm{ml}(n=4)$. Error bar indicates SD. ${ }^{*} p<0.05,{ }^{* *} p<0.01,{ }^{* * *} p<0.001$. n.S., No significance; CHX, cycloheximide.

ways important for axon pathfinding by focusing initially on the controversial role of local protein synthesis (Roche et al., 2009). First, we examined whether components of the translational machinery are present in ES-MNs. We detected immunoreactivity for $\mathrm{P}$ ribosomal proteins (Fig. $3 A$ ) and the translation initiation factor eIF4E (Fig. $3 B, C$ ) in cervical and brachiothoracic motor axons and growth cones in both RALDH2-positive and -negative axons.
In addition, we confirmed the presence of axonally transported $\beta$-actin mRNA (Bassell et al., 1998) in a subset of cervical and brachiothoracic motor axons (Fig. 3D; data not shown) (Rossoll et al., 2003), while Slit2 mRNA (Fig. 3E) is not detected in the axonal compartment of these neurons. Thus, ESC-derived motor axons contain key components of the translational machinery, suggesting that growth cone responses to guidance cues might engage this system. 
To examine the role of protein synthesis in ephrin-Amediated axon collapse, we performed collapse assays on motor axons pretreated with protein synthesis inhibitor cycloheximide $(10 \mu \mathrm{M}) 5 \mathrm{~min}$ before the addition of ephrin-A5. We observed that neither the high concentration of ephrin-A5 that collapsed the majority of growth cones nor the low concentration that elicited subtype-specific collapse depended on protein synthesis (Fig. $2 E)$. In conclusion, ephrin-A5-induced motor neuron growth cone collapse does not appear to require newly synthesized proteins.

\section{Concentration-dependent response of cervical and} brachiothoracic ES-MNs to Sema3a

To determine whether ES-MN collapse is generally protein synthesis independent, we investigated motor axon behavior upon application of secreted semaphorins. Sema3a and Sema3f control motor axon fasciculation and guidance in vivo and in vitro (Fig $1 A, B$ ) (Cohen et al., 2005; Huber et al., 2005; Moret et al., 2007; Haupt and Huber, 2008; Haupt et al., 2010; Huettl et al., 2011) and the dependence of Sema3a response on local protein synthesis has been extensively documented (Campbell and Holt, 2001; Li et al., 2004, 2009; Piper et al., 2005; Wu et al., 2005).

The dose response of cervical and brachiothoracic ES-MNs to Sema3a revealed that, while both subtypes respond to a high concentration $(900 \mathrm{ng} / \mathrm{ml})$ of Sema3a, brachiothoracic ES-MNs were significantly more sensitive to Sema3a at $300 \mathrm{ng} / \mathrm{ml}(68.2 \%$ brachiothoracic vs $42.3 \%$ cervical, $p<0.01$ ) (Fig. $4 A$ ). We examined whether this differential response was due to an increased sensitivity of limb-innervating motor neurons to Sema3a. We exposed brachiothoracic ES-MNs to $300 \mathrm{ng} / \mathrm{ml}$ Sema3a and determined the collapse rate of RALDH2 ${ }^{+}$(LMC) and RALDH2 ${ }^{-}$ axons. Interestingly, both populations of axons responded equally well (data not shown), suggesting that the higher sensitivity of limb level brachial ES-MNs to Sema3a represents a segmental difference between cervical and brachial motor neurons. A similar segmental difference in Sema3a responsiveness has been reported previously between primary lumbar and thoracic motor neurons (Cohen et al., 2005).

\section{Protein synthesis-dependent and -independent collapse in response to Sema3a}

Having established the dose response of ES-MNs to Sema3a, we tested its dependence on protein synthesis. Inhibition of protein synthesis had little effect on the collapse of brachiothoracic motor neuron growth cones under the high $(900 \mathrm{ng} / \mathrm{ml})$ concentration of Sema3a but significantly attenuated the collapse in response to lower concentrations (at $300 \mathrm{ng} / \mathrm{ml}: 73.4 \%$ vs $56.7 \%, p<0.01$; at $100 \mathrm{ng} / \mathrm{ml}: 68.2 \%$ vs $48.4 \%, p<0.001$ ) (Fig. 4 B). These observations indicate that the synthesis of new proteins is required for growth cone collapse at a low concentration of Sema3a. However, a high concentration of Sema3a appears to activate a qualitatively distinct signal transduction pathway that does not rely on protein synthesis. We were however concerned that the high Sema3a concentration might trigger nonphysiological growth cone collapse due to its potential toxicity. We therefore examined whether long-term exposure of motor axons to $900 \mathrm{ng} / \mathrm{ml} \mathrm{Sema3a}$ will result in irreversible growth cone collapse, axon retraction, or even death of spinal motor neurons. Not only that we did not observe a significant loss of motor neurons after $16 \mathrm{~h}$ of treatment with high Sema3a concentration (data not shown), but within $3 \mathrm{~h}$ many axons became desensitized, recovered, and elaborated growth cones to a degree comparable to control cultures (Fig. $4 C)$. Furthermore, preincubation of motor neurons with an Nrp1
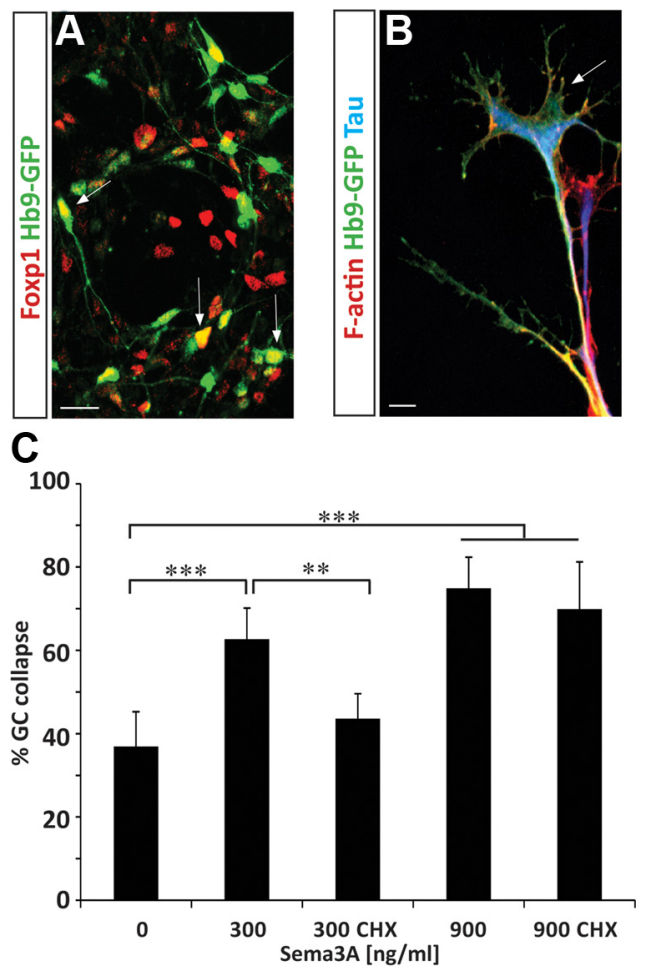

Figure 5. Bimodal response of human ES-MNs to Sema3a. $\boldsymbol{A}$, Human ESC-derived motor neurons (Hb9-GFP) differentiated upon RA and Hh treatment acquire LMC (GFP ${ }^{+}$, Foxp1 ${ }^{+}$, arrows) and non-LMC identities (GFP+). $\boldsymbol{B}$, Human ES-MNs grown on laminin demonstrate elaborated growth cones with F-actin-rich filopodia (phalloidin staining in red). C, Human ES-MNs are responsive to Sema3a. Growth cone collapse in response to $300 \mathrm{ng} / \mathrm{ml}$ Sema3a is protein synthesis dependent (significantly attenuated by cycloheximide; $n=2$ ), while response to $900 \mathrm{ng} / \mathrm{ml}$ is protein synthesis independent (two-way ANOVA with post hoc analysis, $\left.{ }^{*} p<0.05,{ }^{* *} p<0.01,{ }^{* * *} p<0.001\right)$. n.s., No significance; CHX, cycloheximide. Error bar indicates SD. Scale bars, $10 \mu \mathrm{m}$.

blocking antibody fully abolished the collapse response to high Sema3a (data not shown). Together, these results indicate that growth cone collapse in response to a high concentration of Sema3a is not due to overall toxicity. Instead, low and high concentrations are engaging different signaling pathways to induce growth cone collapse of brachiothoracic motor neurons.

\section{Cervical ES-MNs lack protein synthesis-dependent response to low Sema3a}

Lower sensitivity of cervical ES-MNs to Sema3a might be due to the absence of the protein synthesis-dependent pathway necessary to transmit low Sema3a signal. Alternatively, both pathways might be still present but due to lower responsiveness, cervical ES-MNs might require higher concentration of Sema3a to respond in a protein synthesis-dependent manner. To distinguish these two scenarios, we first determined whether low Sema3a concentration can activate the translation machinery in ES-MN axons. A key step in translation activation is the phosphorylation of $4 \mathrm{E}-\mathrm{BP} 1$, which disrupts the interaction between 4E-BP1 and the cap binding protein eIF4E. Axonal phosphorylation of 4E-BP1 increases upon exposure to guidance cues in protein synthesisdependent guidance events (Campbell and Holt, 2001). Brachial and cervical ES-MNs were thus exposed to low Sema3a concentration, fixed, and stained for P-4EBP1. A low concentration of Sema3a increased phospho-4E-BP1 (P-4E-BP1) compared to control (0.21 \pm 0.023 vs $0.36 \pm 0.06, p<0.05$ ) (Fig. $4 E, H$ ) in brachial but not cervical motor neurons $(0.24 \pm 0.02)$ (Fig. $5 F, H)$. Application of a 
A

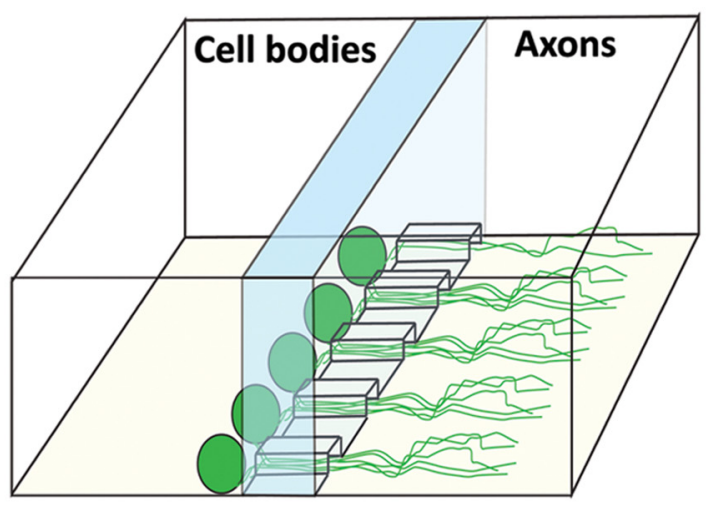

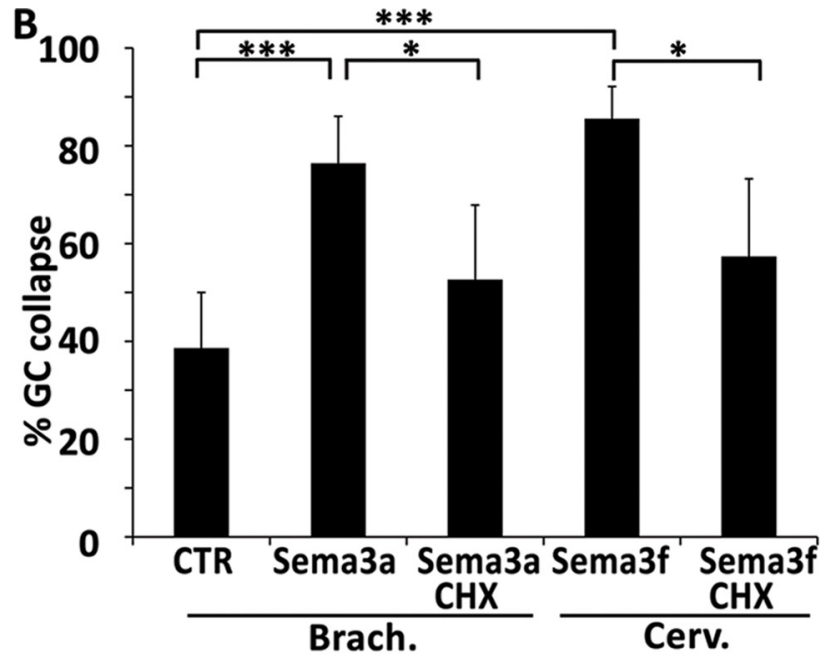

Brach.
Cerv.
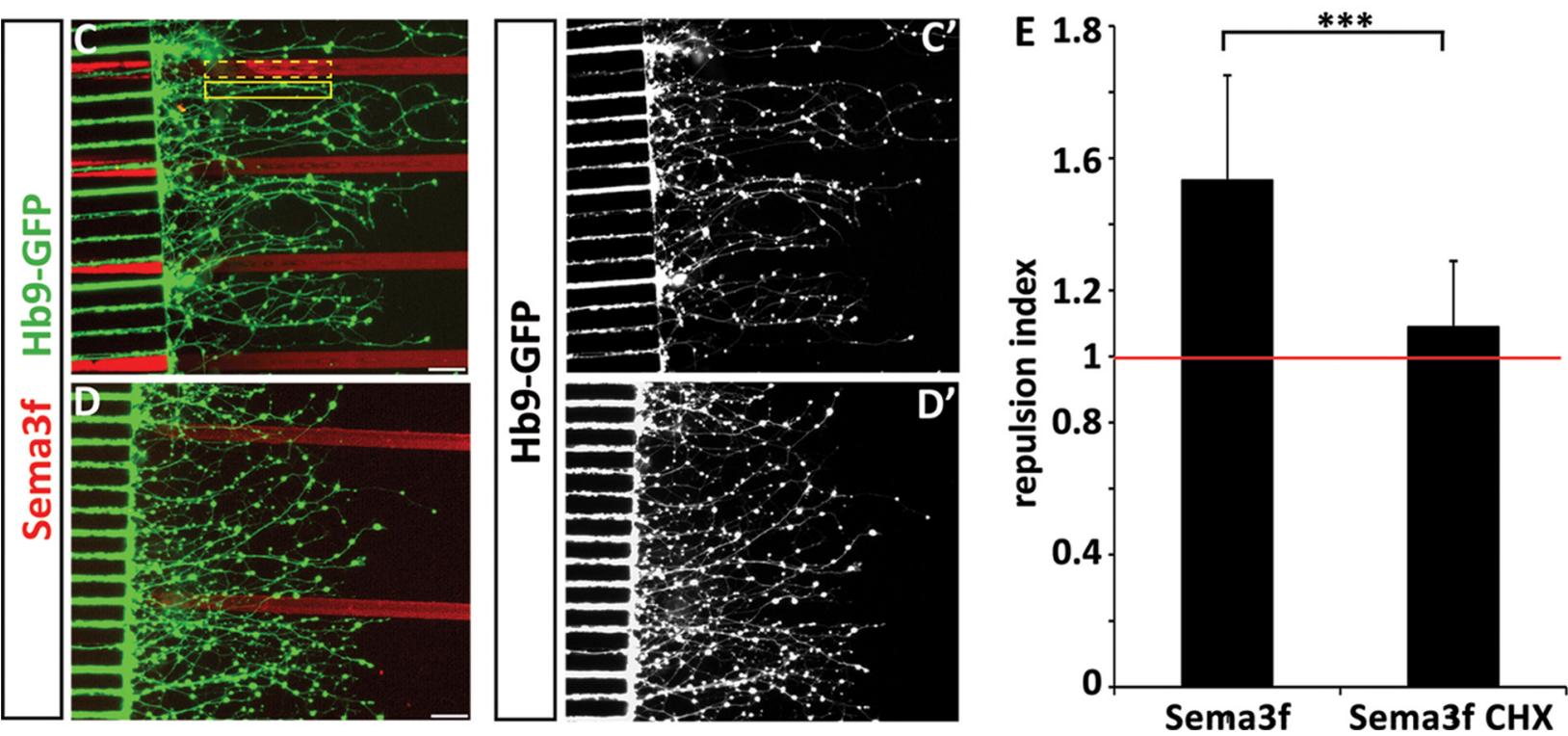

Figure 6. Axonal protein synthesis is required for semaphorin-mediated collapse and guidance. $A$, Graphic representation of a microfluidic chamber. Differentiated embryoid bodies are plated in one compartment of the chamber. Axons grow through microchannels and enter the "axonal compartment" (see also Shi et al., 2010). B, Sema3a-induced collapse of brachiothoracic (Brach.) motor axons and Sema3f-induced collapse of cervical (Cerv.) motor axons are attenuated when cycloheximide (CHX) is applied to the axonal compartment of the microfluidic chamber. $\mathbf{C}-\boldsymbol{D}^{\prime}$, Micropatterned Sema3f stripes (red) are avoided by cervical motor axons $\left(\boldsymbol{C}, \boldsymbol{C}^{\prime}\right)$, but treatment of axons with cycloheximide attenuates Sema3f avoidance $\left(\boldsymbol{D}, \boldsymbol{D}^{\prime}\right)$. Scale bars, $40 \mu \mathrm{m} . \boldsymbol{E}$, The repulsion index is calculated as a ratio of GFP intensity in two adjacent regions of interest of identical size, one covering the laminin stripe ( $\boldsymbol{C}$, solid yellow line), and the second covering the Sema3f stripe (C, dashed yellow line). The repulsion mediated by Sema3f (index 1.53) is significantly ( $t$ test, $p<0.001$ ) attenuated by cycloheximide treatment (index 1.088$)(n=16$ stripes/condition).

high concentration of Sema3a $(900 \mathrm{ng} / \mathrm{ml})$ on cervical ES-MNs tends to increase P-4E-BP1, but the difference with the control condition was not significant mostly due to a greater variability in P-4EBP-1 between growth cones (Fig. 4G,H). This observation suggests that cervical ES-MNs do not significantly activate local protein synthesis in response to Sema3a.

We then examined whether local protein synthesis is required for the collapse response of cervical motor axons to the higher doses of Sema3a. We observed that treatment of cultures with cycloheximide did not significantly attenuate growth cone collapse elicited by $900 \mathrm{ng} / \mathrm{ml} \mathrm{Sema3a}$ (Fig. 4I). Therefore, despite a tendency to stimulate translation, high Sema3a recruits a signaling pathway downstream of Nrp1, which causes growth cone collapse independently of the synthesis of new proteins.

Sema3f elicits protein synthesis-dependent growth cone collapse

In contrast to Sema3a, both cervical and brachiothoracic motor neurons exhibit similar sensitivity to Sema3f treatment (data not shown). We took advantage of this response to examine whether the absence of protein synthesis-dependent signaling guidance pathway at low semaphorin concentration is a general property of cervical motor neurons. In contrast to Sema3a, Sema3f increased P-4EBP-1 in cervical ES-MN growth cones (Fig. $4 H$ ). In addition, we observed that the collapse of cervical motor axon induced by Sema3f at low and medium concentrations is protein synthesis dependent (attenuated by cycloheximide; $p<0.001$ ) but becomes insensitive to cycloheximide treatment under higher concentrations, mimicking the effects of Sema3a on brachiothoracic motor neurons (Fig. 4J). Thus, cervical motor neurons are capable of engaging the protein synthesis pathway in response to low concentrations of guidance cue, but selectively lack the high-affinity signal transduction cascade linking low concentrations of Sema3a to the protein translation machinery. Therefore low and high concentrations of Sema3a and Sema3f engage two distinct (protein synthesis-dependent and -independent) signal transduction pathways, both leading to growth cone collapse. 




Figure 7. Subtype-dependent bimodal response to semaphorins is distinguished by protein synthesis requirement. Protein synthesis-dependent and -independent pathways are activated by different concentrations of Sema $3 \mathrm{f}$ in both cervical and brachiothoracic motor neurons. In contrast, the low protein synthesis-dependent Sema3a pathway is observed only in brachiothoracic motor neurons, while both populations of neurons are responsive to high Sema3a (in a protein synthesis-independent manner). The cervical motor neurons appear to lack the receptors or the components of the transduction cascade linking low concentration of Sema3a to the protein translation machinery. Collapse induced by ephrin-As at all tested concentrations is independent of the protein synthesis pathway. prot., Protein.

\section{Concentration-dependent pathways are conserved in human motor neurons}

The protein synthesis requirement for guidance cue response has been demonstrated in several species including Xenopus, mouse, and rat (Campbell and Holt, 2001; Li et al., 2004; Wu et al., 2005). The ES-MN system provides a unique opportunity to study axon guidance of human motor neurons, which are otherwise inaccessible to experimentation. Human ES-MNs derived under the RA/Hh condition ( $\mathrm{Li}$ et al., 2005; Boulting et al., 2011) contain a sizable population of Foxp1 LMC neurons, resembling the composition of mouse brachiothoracic ES-MNs (Fig. 5A) (Patani et al., 2011). When plated on a laminin substrate, human ES-MNs extend axons terminated by well elaborated growth cones (Fig. $5 B)$. The growth cone collapse assay revealed that human ESMNs respond to both low (300 ng/ml; $p<0.001)$ and high $(900$ $\mathrm{ng} / \mathrm{ml} ; p<0.001)$ concentrations of Sema3a, and that only the response to a low concentration of Sema3a is attenuated by the protein synthesis inhibitor cycloheximide $(62.7 \%$ vs $43.6 \%, p<$ 0.01) (Fig. 6C).

Together, these results demonstrate that response to guidance cues as well as signaling pathways can be studied in human motor neurons, and that concentration-dependent protein synthesismediated collapse is a conserved mechanism for motor axon guidance.

\section{Motor neuron response to Sema3a and Sema3f requires local protein synthesis in axons}

Several studies have provided strong evidence that protein synthesis recruited during the response to guidance cues is executed locally within distal axons or growth cones (Campbell and Holt, 2001; Ming et al., 2002; Wu et al., 2005; Hengst et al., 2009). The in vitro system offered an opportunity to determine whether the relatively rapid (20 $\mathrm{min}$ ) collapse of growth cones in response to semaphorins depends on local protein synthesis in motor axons. We used microfluidic chambers in which distal segments ( $>250 \mu \mathrm{m}$ from cell body) of mouse ES-MN axons and growth cones can be biochemically isolated from cell bodies (Shi et al., 2010). We observed that application of cycloheximide to the axonal compartment significantly attenuated the collapse of brachiothoracic growth cones to low concentrations of Sema3a as well as the response of cervical growth cones to Sema3f (Fig. 6B). Therefore, axonal protein synthesis is required for growth cone collapse.

Growth cone collapse assay is a simplified method to examine responses of neurons to guidance cues. To determine whether local protein synthesis might be important for a more natural form of axon pathfinding, we combined the microfluidic system with stripe assays. To quantify the response of axons to patterned stripes, we calculated a guidance index as a ratio of motor axons growing on laminin and on an adjacent patterned stripe. When ES-MNs are cultured on stripes made of control Fc proteins, the guidance index is close to 1 $(0.98 \pm 0.09$; data not shown $)$, indicating that axons exhibit little pathfinding preference. In contrast, ES-MN axons exhibit strong repulsion to micropatterned Sema3f (guidance index $1.53 \pm 0.31$ ) (Fig. $6 C, E)$. Interestingly, when axonal compartment is treated with cycloheximide, ES-MN axons lose their sensitivity to Sema3f and the guidance index is significantly decreased to $1.088 \pm 0.2(p<$ 0.001 ) (Fig. $6 D, E$ ). These results suggest that even the contact guidance of motor axons along semaphorin territories relies on local protein synthesis-dependent pathway.

\section{Discussion}

In this study, we established ES-MNs as a robust and convenient system to model and study motor axon subtype-specific responses and axon guidance mechanisms. We demonstrate the following: (1) in vitro cultured ES-MNs acquire competence to respond to developmentally relevant guidance cues; (2) the responses are motor neuron subtype specific; (3) the subtypespecific responses depend on the concentration of guidance cues; and (4) responses to low and high concentrations of semaphorins rely on qualitatively distinct intracellular processes (Fig. 7). Thus, ES-MNs can be used for pharmacological and biochemical analysis of molecular mechanisms engaged in subtype-specific axon guidance.

\section{ES-MNs as a tool to study motor axon guidance}

Several lines of evidence support our conclusion that ES-MNs acquire axon guidance properties and specificity analogous to in vivo motor neurons. Using growth cone collapse assay, we established that ES-MNs possess a differential sensitivity to guidance cues according to their columnar identity. Among the subtypes of ES-MNs generated at brachiothoracic level, non-LMC motor neurons respond more efficiently to ephrin-A5 compared with LMC neurons. This is consistent with the observation that the majority of LMC neurons generated under this condition are of the LMCm divisional subtype that is guided by type B but not type A ephrins in vivo (Luria et al., 2008; Peljto et al., 2010). Furthermore, we determined that brachiothoracic ES-MNs are more sensitive to Sema3a compared with cervical ES-MNs. Cohen et al. (2005) observed that primary lumbar motor neurons are more sensitive to Sema3a than thoracic ones. These results raise the possibility that higher sensitivity to Sema3a is a general property of limb-level motor neurons. Indeed, Sema3a has been implicated in the controlled ingrowth of motor axons into the developing limb territory in vivo (Huber et al., 2005). Together, 
these results demonstrate that in vitro generated motor neurons acquire receptors and signal transduction machinery necessary for differential responsiveness to guidance cues with well defined roles in motor axon pathfinding in vivo (Eberhart et al., 2000; Helmbacher et al., 2000; Kania et al., 2000; Huber et al., 2005; Marquardt et al., 2005; Gallarda et al., 2008; Haupt et al., 2010; Huettl et al., 2011; Kao and Kania, 2011; Wang et al., 2011). Finally, derivation of human motor neurons from embryonic or induced pluripotent stem cells (Li et al., 2005; Dimos et al., 2008; Boulting et al., 2011), provides the first robust platform to study axon guidance preference of human motor neurons. Understanding the molecular mechanisms underlying human motor system wiring might prove invaluable for the development of effective cell replacement therapies for motor neuron diseases.

\section{Local protein synthesis-dependent and -independent responses to guidance cues}

Local protein synthesis has been shown to be necessary for growth cone response to attractive and repulsive cues (including netrin-1, Sema3a, Slit2, Bdnf, Ngf, En-2, ephrin-As, PACAP) in DRGs, RGCs, hippocampal neurons, and sympathetic neurons (Campbell and Holt, 2001; Ming et al., 2002; Guirland et al., 2003; Li et al., 2004, 2009; Brunet et al., 2005; Wu et al., 2005; Piper et al., 2006; Willis et al., 2007; Cox et al., 2008; Hengst et al., 2009; Wizenmann et al., 2009; Andreassi et al., 2010). Roche et al. (2009) recently challenged this notion by demonstrating that Sema3a, ephrin-A2, Slit3, and Sema6a can induce collapse of DRG, retinal, or sympathetic neuron growth cones in the presence of translation inhibitors (Roche et al., 2009). We therefore performed a detailed analysis of ES-MN growth cone collapse responses and found that, while protein synthesis is dispensable for ephrin-A5-triggered growth cone collapse (Mann et al., 2003; Roche et al., 2009; Nie et al., 2010), low concentrations of Sema3f and Sema3a induce a local protein synthesis-dependent collapse.

Importantly, our study revealed that the requirement for protein synthesis is strictly dependent on the concentration of guidance cue tested. At higher concentrations of Sema3a or Sema3f $(900 \mathrm{ng} / \mathrm{ml})$, the triggered growth cone collapse is protein synthesis independent. In their study, Roche et al. (2009) tested the responses to Sema3a at a single relatively high concentration $(500 \mathrm{ng} / \mathrm{ml})$. Thus, our findings might provide a rational explanation for the reported lack of protein synthesis dependence in Sema3a-mediated growth cone collapse. In summary, our study reveals that molecular mechanisms engaged during growth cone collapse depend on the following three important factors: the type of guidance cue, its concentration, and the precise subtype of examined neurons. Furthermore, our observation that ES-MNs, when plated as embryoid bodies (i.e., with intact, uninjured axons), show a protein synthesis response to guidance cues rules out the possibility that only regenerating axons require local protein synthesis to respond to extracellular stimuli.

\section{Bimodal response of motor axons to guidance cues}

We found that low concentrations and high concentrations of semaphorins induce qualitatively distinct signaling pathways in responding growth cones (Fig. 7). The induction of different signaling pathways depending on cue concentration has been previously demonstrated in other systems but was not reported for axon guidance molecules. For example Wnt3A induces Wnt canonical and noncanonical pathways in primary human articular chondrocytes, depending on its concentrations (Nalesso et al., 2011). Similarly, low and high EGF concentrations regulate distinct cellular outputs through the induction of different signaling cascades downstream of EGF receptor in breast cancer cells and mammary epithelial cells (Sigismund et al., 2008; Krall et al., 2011). The ability of growth cones to differentially interpret low and high concentrations of guidance cues might be critical for proper axon pathfinding in a complex embryonic environment. Axon guidance is a highly dynamic process during which growth cones constantly adjust their responsiveness to attractive or repulsive signals. This ensures that axons maintain optimal sensitivity to local changes in guidance cue concentration. We found that at a low concentration of cues ES-MNs respond in a subtype-selective manner but that this specificity is eroded at higher concentrations. We can speculate that high levels of cues might be encountered by growth cones that veered off their normal path into nonpermissive territory. General growth cone collapse response under such circumstances might be primarily responsible for motor axon fasciculation and restricted growth along defined nerve trajectories. Indeed, defects in fasciculation are prominent features of Nrp1- or Nrp2-null mice and affect most motor nerves regardless of motor neuron subtype identity (Huber et al., 2005). In contrast, the low concentration response might be necessary for the discrimination of subtle differences in the guidance cue levels at branchpoints and therefore might be critical for the ultimate subtype-specific axon navigation to correct synaptic targets. The existence of a bimodal response to guidance cues might be a general property of all nerve cells. In agreement, (R. P. C. Manns, G. M. W. Cook, C. E. Holt, and R. J. Keynes, personal communication) have determined that exposure of DRG growth cones to a low concentration of Sema3a activates a nitric oxide synthase and mammalian target of rapamycin (mTOR)/ protein synthesis-dependent pathway, while a higher Sema3a concentration induces a GSK-3 $\beta$ (glycogen synthase kinase- $3 \beta$ )dependent/protein synthesis-independent pathway.

Overall, these results suggest that activation of discrete pathways by low and high concentrations of guidance cues might increase the diversity of possible responses of axons to the arguably limited number of guidance cues involved in the wiring of the nervous system (Kolodkin and Tessier-Lavigne, 2011). Finally, repulsive or inhibitory signals contribute to the limited regenerative capacity of the adult nervous system (Giger et al., 2010). If a similar bimodal response system is active in injured axons, it might be necessary to develop combinatorial strategies to overcome the repulsive environment of the adult nervous system and to promote more effective regeneration and recovery.

\section{References}

Andreassi C, Zimmermann C, Mitter R, Fusco S, De Vita S, Saiardi A, Riccio A (2010) An NGF-responsive element targets myo-inositol monophosphatase-1 mRNA to sympathetic neuron axons. Nat Neurosci 13:291-301.

Bassell GJ, Zhang H, Byrd AL, Femino AM, Singer RH, Taneja KL, Lifshitz LM, Herman IM, Kosik KS (1998) Sorting of $\beta$-actin mRNA and protein to neurites and growth cones in culture. J Neurosci 18:251-265.

Batish M, Raj A, Tyagi S (2011) Single molecule imaging of RNA in situ. Methods Mol Biol 714:3-13.

Bonanomi D, Pfaff SL (2010) Motor axon pathfinding. Cold Spring Harb Perspect Biol 2:a001735.

Boulting GL, Kiskinis E, Croft GF, Amoroso MW, Oakley DH, Wainger BJ, Williams DJ, Kahler DJ, Yamaki M, Davidow L, Rodolfa CT, Dimos JT, Mikkilineni S, MacDermott AB, Woolf CJ, Henderson CE, Wichterle H, Eggan K (2011) A functionally characterized test set of human induced pluripotent stem cells. Nat Biotechnol 29:279-286. 
Brown JA, Wysolmerski RB, Bridgman PC (2009) Dorsal root ganglion neurons react to semaphorin $3 \mathrm{~A}$ application through a biphasic response that requires multiple myosin II isoforms. Mol Biol Cell 20:1167-1179.

Brunet I, Weinl C, Piper M, Trembleau A, Volovitch M, Harris W, Prochiantz A, Holt C (2005) The transcription factor Engrailed-2 guides retinal axons. Nature 438:94-98.

Campbell DS, Holt CE (2001) Chemotropic responses of retinal growth cones mediated by rapid local protein synthesis and degradation. Neuron 32:1013-1026.

Cohen S, Funkelstein L, Livet J, Rougon G, Henderson CE, Castellani V, Mann F (2005) A semaphorin code defines subpopulations of spinal motor neurons during mouse development. Eur J Neurosci 21:1767-1776.

Cox LJ, Hengst U, Gurskaya NG, Lukyanov KA, Jaffrey SR (2008) Intraaxonal translation and retrograde trafficking of CREB promotes neuronal survival. Nat Cell Biol 10:149-159.

Dasen JS, Jessell TM (2009) Hox networks and the origins of motor neuron diversity. Curr Top Dev Biol 88:169-200.

Dimos JT, Rodolfa KT, Niakan KK, Weisenthal LM, Mitsumoto H, Chung W, Croft GF, Saphier G, Leibel R, Goland R, Wichterle H, Henderson CE, Eggan K (2008) Induced pluripotent stem cells generated from patients with ALS can be differentiated into motor neurons. Science 321:1218-1221.

Eberhart J, Swartz M, Koblar SA, Pasquale EB, Tanaka H, Krull CE (2000) Expression of EphA4, ephrin-A2 and ephrin-A5 during axon outgrowth to the hindlimb indicates potential roles in pathfinding. Dev Neurosci 22:237-250

Gallarda BW, Bonanomi D, Müller D, Brown A, Alaynick WA, Andrews SE, Lemke G, Pfaff SL, Marquardt T (2008) Segregation of axial motor and sensory pathways via heterotypic trans-axonal signaling. Science 320:233-236.

Giger RJ, Hollis ER 2nd, Tuszynski MH (2010) Guidance molecules in axon regeneration. Cold Spring Harb Perspect Biol 2:a001867.

Guirland C, Buck KB, Gibney JA, DiCicco-Bloom E, Zheng JQ (2003) Direct cAMP signaling through G-protein-coupled receptors mediates growth cone attraction induced by pituitary adenylate cyclase-activating polypeptide. J Neurosci 23:2274-2283.

Gumy LF, Tan CL, Fawcett JW (2010) The role of local protein synthesis and degradation in axon regeneration. Exp Neurol 223:28-37.

Haupt C, Huber AB (2008) How axons see their way-axonal guidance in the visual system. Front Biosci 13:3136-3149.

Haupt C, Kloos K, Faus-Kessler T, Huber AB (2010) Semaphorin 3ANeuropilin-1 signaling regulates peripheral axon fasciculation and pathfinding but not developmental cell death patterns. Eur J Neurosci 31:1164-1172.

Helmbacher F, Schneider-Maunoury S, Topilko P, Tiret L, Charnay P (2000) Targeting of the EphA4 tyrosine kinase receptor affects dorsal/ventral pathfinding of limb motor axons. Development 127:3313-3324.

Hengst U, Deglincerti A, Kim HJ, Jeon NL, Jaffrey SR (2009) Axonal elongation triggered by stimulus-induced local translation of a polarity complex protein. Nat Cell Biol 11:1024-1030.

Huber AB, Kania A, Tran TS, Gu C, De Marco Garcia N, Lieberam I, Johnson D, Jessell TM, Ginty DD, Kolodkin AL (2005) Distinct roles for secreted semaphorin signaling in spinal motor axon guidance. Neuron 48:949-964.

Huettl RE, Soellner H, Bianchi E, Novitch BG, Huber AB (2011) Npn-1 contributes to axon-axon interactions that differentially control sensory and motor innervation of the limb. PLoS Biol 9:e1001020.

Jaffrey SR (2009) Collapse data not supporting claim. J Neurosci. eLetter published March 10, 2009.

Jung H, Holt CE (2011) Local translation of mRNAs in neural development. Wiley Interdiscip Rev RNA 2:153-165.

Kania A, Jessell TM (2003) Topographic motor projections in the limb imposed by LIM homeodomain protein regulation of ephrin-A:EphA interactions. Neuron 38:581-596.

Kania A, Johnson RL, Jessell TM (2000) Coordinate roles for LIM homeobox genes in directing the dorsoventral trajectory of motor axons in the vertebrate limb. Cell 102:161-173.

Kao TJ, Kania A (2011) Ephrin-mediated cis-attenuation of Eph receptor signaling is essential for spinal motor axon guidance. Neuron 71:76-91.

Kolodkin AL, Tessier-Lavigne M (2011) Mechanisms and molecules of neuronal wiring: a primer. Cold Spring Harbor Perspect Biol 3:a001727.

Krall JA, Beyer EM, MacBeath G (2011) High- and low-affinity epidermal growth factor receptor-ligand interactions activate distinct signaling pathways. PLoS One 6:e15945.

Li C, Sasaki Y, Takei K, Yamamoto H, Shouji M, Sugiyama Y, Kawakami T, Nakamura F, Yagi T, Ohshima T, Goshima Y (2004) Correlation between semaphorin3A-induced facilitation of axonal transport and local activation of a translation initiation factor eukaryotic translation initiation factor 4E. J Neurosci 24:6161-6170.

Li C, Bassell GJ, Sasaki Y (2009) Fragile X mental retardation protein is involved in protein synthesis-dependent collapse of growth cones induced by semaphorin-3A. Front Neural Circuits 3:11.

Li XJ, Du ZW, Zarnowska ED, Pankratz M, Hansen LO, Pearce RA, Zhang SC (2005) Specification of motoneurons from human embryonic stem cells. Nat Biotechnol 23:215-221.

Luria V, Krawchuk D, Jessell TM, Laufer E, Kania A (2008) Specification of motor axon trajectory by ephrin-B:EphB signaling: symmetrical control of axonal patterning in the developing limb. Neuron 60:1039-1053.

Mann F, Miranda E, Weinl C, Harmer E, Holt CE (2003) B-type Eph receptors and ephrins induce growth cone collapse through distinct intracellular pathways. J Neurobiol 57:323-336.

Marquardt T, Shirasaki R, Ghosh S, Andrews SE, Carter N, Hunter T, Pfaff SL (2005) Coexpressed EphA receptors and ephrin-A ligands mediate opposing actions on growth cone navigation from distinct membrane domains. Cell 121:127-139.

Ming GL, Wong ST, Henley J, Yuan XB, Song HJ, Spitzer NC, Poo MM (2002) Adaptation in the chemotactic guidance of nerve growth cones. Nature 417:411-418.

Moret F, Renaudot C, Bozon M, Castellani V (2007) Semaphorin and neuropilin co-expression in motoneurons sets axon sensitivity to environmental semaphorin sources during motor axon pathfinding. Development 134:4491-4501.

Nalesso G, Sherwood J, Bertrand J, Pap T, Ramachandran M, De Bari C, Pitzalis C, Dell'accio F (2011) WNT-3A modulates articular chondrocyte phenotype by activating both canonical and noncanonical pathways. J Cell Biol 193:551-564.

Nie D, Di Nardo A, Han JM, Baharanyi H, Kramvis I, Huynh T, Dabora S, Codeluppi S, Pandolfi PP, Pasquale EB, Sahin M (2010) Tsc2-Rheb signaling regulates EphA-mediated axon guidance. Nat Neurosci $13: 163-172$.

Ohta K, Iwamasa H, Drescher U, Terasaki H, Tanaka H (1997) The inhibitory effect on neurite outgrowth of motoneurons exerted by the ligands ELF-1 and RAGS. Mech Dev 64:127-135.

Patani R, Hollins AJ, Wishart TM, Puddifoot CA, Alvarez S, de Lera AR, Wyllie DJ, Compston DA, Pedersen RA, Gillingwater TH, Hardingham GE, Allen ND, Chandran S (2011) Retinoid-independent motor neurogenesis from human embryonic stem cells reveals a medial columnar ground state. Nat Commun 2:214.

Peljto M, Dasen JS, Mazzoni EO, Jessell TM, Wichterle H (2010) Functional diversity of ESC-derived motor neuron subtypes revealed through intraspinal transplantation. Cell Stem Cell 7:355-366.

Petros TJ, Bryson JB, Mason C (2010) Ephrin-B2 elicits differential growth cone collapse and axon retraction in retinal ganglion cells from distinct retinal regions. Dev Neurobiol 70:781-794.

Piper M, Salih S, Weinl C, Holt CE, Harris WA (2005) Endocytosisdependent desensitization and protein synthesis-dependent resensitization in retinal growth cone adaptation. Nat Neurosci 8:179-186.

Piper M, Anderson R, Dwivedy A, Weinl C, van Horck F, Leung KM, Cogill E, Holt C (2006) Signaling mechanisms underlying Slit2-induced collapse of Xenopus retinal growth cones. Neuron 49:215-228.

Raj A, van den Bogaard P, Rifkin SA, van Oudenaarden A, Tyagi S (2008) Imaging individual mRNA molecules using multiple singly labeled probes. Nat Methods 5:877-879.

Roche FK, Marsick BM, Letourneau PC (2009) Protein synthesis in distal axons is not required for growth cone responses to guidance cues. J Neurosci 29:638-652.

Rossoll W, Jablonka S, Andreassi C, Kröning AK, Karle K, Monani UR, Sendtner M (2003) Smn, the spinal muscular atrophy-determining gene product, modulates axon growth and localization of beta-actin mRNA in growth cones of motoneurons. J Cell Biol 163:801-812.

Shi P, Nedelec S, Wichterle H, Kam LC (2010) Combined microfluidics/ protein patterning platform for pharmacological interrogation of axon pathfinding. Lab Chip 10:1005-1010.

Sigismund S, Argenzio E, Tosoni D, Cavallaro E, Polo S, Di Fiore PP (2008) 
Clathrin-mediated internalization is essential for sustained EGFR signaling but dispensable for degradation. Dev Cell 15:209-219.

Sockanathan S, Jessell TM (1998) Motor neuron-derived retinoid signaling specifies the subtype identity of spinal motor neurons. Cell 94:503-514.

Soundararajan P, Fawcett JP, Rafuse VF (2010) Guidance of postural motoneurons requires MAPK/ERK signaling downstream of fibroblast growth factor receptor 1. J Neurosci 30:6595-6606.

Wang L, Klein R, Zheng B, Marquardt T (2011) Anatomical coupling of sensory and motor nerve trajectory via axon tracking. Neuron 71: 263-277.

Wichterle H, Lieberam I, Porter JA, Jessell TM (2002) Directed differentiation of embryonic stem cells into motor neurons. Cell 110:385-397.

Willis DE, van Niekerk EA, Sasaki Y, Mesngon M, Merianda TT, Williams
GG, Kendall M, Smith DS, Bassell GJ, Twiss JL (2007) Extracellular stimuli specifically regulate localized levels of individual neuronal mRNAs. J Cell Biol 178:965-980.

Wizenmann A, Brunet I, Lam JS, Sonnier L, Beurdeley M, Zarbalis K, Weisenhorn-Vogt D, Weinl C, Dwivedy A, Joliot A, Wurst W, Holt C, Prochiantz A (2009) Extracellular Engrailed participates in the topographic guidance of retinal axons in vivo. Neuron 64:355-366.

Wu KY, Hengst U, Cox LJ, Macosko EZ, Jeromin A, Urquhart ER, Jaffrey SR (2005) Local translation of RhoA regulates growth cone collapse. Nature 436:1020-1024.

Yohn DC, Miles GB, Rafuse VF, Brownstone RM (2008) Transplanted mouse embryonic stem-cell-derived motoneurons form functional motor units and reduce muscle atrophy. J Neurosci 28:12409-12418. 